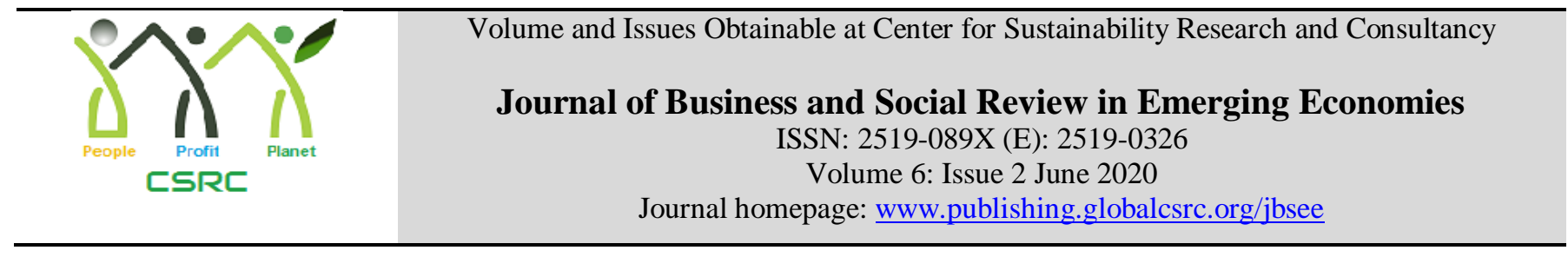

\title{
Entrepreneurship as a Sustainable Solution for the Female Graduates in the SME Sector of Bangladesh
}

\author{
${ }^{1}$ Nusrat Hafiz, ${ }^{2}$ Ahmad Shaharudin Abdul Latiff \\ ${ }^{1}$ Putra Business School, University Putra Malaysia, Malaysia nusrat.phd_mgt18@grad.putrabs.edu.my \\ ${ }^{2}$ Putra Business School, University Putra Malaysia, Malaysia shaharudin@putrabs.edu.my
}

\begin{tabular}{l}
\hline ARTICLE DETAILS \\
\hline History \\
Revised format: May 2020 \\
Available Online: June 2020
\end{tabular}

Keywords

Female graduates ,

Women entrepreneurs, small

and medium enterprises,

Bangladesh, sustainable

solutions, issues

JEL Classification

L26, L31

\begin{abstract}
Female entrepreneurship is a sustainable entrepreneurial activity by women, individually or in a group. This relatively new phenomenon has been gaining attention in developing countries like Bangladesh. The female graduates of the country represent an important yet untapped segment of entrepreneurship. The paper critically evaluates the current situation of this segment and finds that several issues, including graduate labor market imbalance, socio-economic impediments, glass ceiling and gender stereotypes, legal challenges relating to gender rights, and inadequate policy implementation limit their capacity to participate in the labor-force besides their male counterparts. The underpinning issues, if not treated prudently, might adversely affect the socio-economic goals of Bangladesh. Entrepreneurship can be considered as a sustainable employment solution for the female graduates, through which they can also contribute to the Small and Medium-sized enterprises (SME) sector of the country. The article proposes practical action plans to reinforce the initiatives by the stakeholders and suggests to make necessary policy changes in order to facilitate graduate female entrepreneurship in the SME sector, enhance sustainability of the sector and convert it into a catalyst for economic growth of Bangladesh.
\end{abstract}

(C) 2020 The authors, under a Creative Commons Attribution-

NonCommercial 4.0

Corresponding author's email address: nusrat.phd_mgt18@grad.putrabs.edu.my

Recommended citation: Hafiz, N., Latif, A.S.A. (2020). Entrepreneurship as a Sustainable Solution for the Female Graduates in the SME Sector of Bangladesh. Journal of Business and Social Review in Emerging Economies, 6 (2) 483-492.

\section{Introduction}

Women entrepreneurship is vital for economic growth (Shoma, 2019) of a country. In Bangladesh, women represent more than $40 \%$ of labor-force and lead to 'private industry revolution' (Islam, Jantan, Hunt, Rahman, \& Abdullah, 2019), the gender gap prevails in ownership of the Small and Medium Enterprises (SMEs) (92.6\% for males versus 7.4\% for females) (Chowdhury, Mintoo, Chowdhury, \& Ahmed, 2010) (Kabeer, 2012), women-owned firms (3-4\% of total business enterprises) (Ahmed M. U., 2014) and among micro-merchants (94,800 out of 1.3 million) (UNCDF, 2019). The graduate females despite being 2.5 times higher than their male-counterparts, often reluctant to join the labor-force for various social, cultural and workplace-related issues (The Daily Star, 2018).

Economists advised the graduates to start entrepreneurial firms that create jobs for themselves and for other 
unemployed graduates (Yunus, 2017) and lead economic growth (Islam, Jantan, Hunt, Rahman, \& Abdullah, 2019). In Bangladesh, SMEs being the most cost-efficient way to instigate GDP growth, suffers various barriers (Alauddin \& Chowdhury, 2015). Females representing 50\% of the unemployed graduates in the country (Khatun, 2018) should be brought into the limelight to create and operate SMEs.

Despite several studies and enormous interest on this topic during the past few decades (Bosma, 2013) (Yunis, Hashim, \& Anderson, 2019), the graduate female entrepreneurship is yet to gain attention. Hence, the study aims to examine the necessity of graduate females to join entrepreneurship is an untapped research domain. The study attempts to fill the gap by exploring the research question: "Is graduate female entrepreneurship a practical solution for the unemployed graduate females of Bangladesh?" focusing the following research objectives:

1) To explore issues faced by unemployed graduate females.

2) To identify the necessity of graduate women to join entrepreneurship.

3) To recommend action-plans to foster entrepreneurship for the female graduates.

\section{Literature Review}

\subsection{The Graduate Female Labor Market}

Graduate unemployment is a phenomenon which is faced by the graduate people with academic degrees. Graduate female unemployment is a similar situation of the females with degrees. The crisis leads to a more depressing scenario than occurred by general employment, as it involves wasteful investment in educating the unemployed graduates which could have been channeled to other productive initiatives. Worldwide, occupational shortages have been a feature of the graduate labor market since the recovery from last recession (Ball, 2018/19). The numerical dominance of female graduates over their male counterparts that have been prevailing since 1995 never translated into success in the graduate labor market (Kempster, 2018/19). The 'gender-based graduate pay-gap' raises controversy for those graduating from similar-standard institutions, being equally qualified or capable to carry out similar jobs (Kempster, 2018/19).

The employment-struggle lowers the confidence level and probability of future earnings by $13.0 \%$ for females compared to $8.4 \%$ for the males (Kletzer \& Fairlie, 2003). It also leads to underemployment, loss of job-satisfaction and motivation, as found in a study by Nanjing University, China about "College Student's Attitudes about Job Seeking and Career" (Salik, Zhiyong, Guoyuan, \& Jiayong , 2015). The gender-wise graduate labor-market imbalance prevails in Bangladesh as despite female students' enrolments at both public and private universities (35.27\% in 2016 from $31.28 \%$ 2009) grew substantially (bbs.portal.gov.bd, 2016), the rate of unemployment is 2.5 times higher for the graduate females than their male counterparts (Quarterly Labor Force Survey of 2015-16 of BBS) (The Daily Star, 2018).

Table 1: Unemployed Graduates of Bangladesh (gender-based)

\begin{tabular}{|l|l|l|l|}
\hline Gender & Graduates & Unemployed graduates & Unemployed graduates (\%) \\
\hline Male & $5,86,166$ & 98,476 & $16.8 \%$ \\
\hline Female & $2,86,725$ & $1,20,425$ & $42 \%$ \\
\hline Source: & (bbs.portal.gov.bd, 2016) & & \\
\hline
\end{tabular}

The unemployment rate of urban graduate female stands at $18.3 \%$ of total unemployment, which is substantially greater than the urban females with no formal education (2.2\%) (Bangladesh Bureau of Statistics, 2018). The key obstacles faced by graduate females towards career-related growth are highlighted below:

A. Social issues: Women are still not encouraged to control life and decision-making (Sarfaraz, Faghih, \& Majd, 2014) and faced with safety concerns, undesirable social norms, employers' reluctance to hire or promote 
females (The Daily Star, 2018), legal and discriminatory trials, lack of policy implications, insufficient institutional support, gender segregation on bread-winning role (Ahmed M. U., 2014) or have own choice to remain at home (SENGUPTA, 2019).

B. Cultural Norms: Patriarchic domination, noncooperative social structures and religious misconceptions (Shoma, 2019) (Islam \& Dogra, 2011) create demotivation for female graduates to join workforce. Parents educate their daughters for having better marriage prospects where the in-laws' high family-income discourage them to work outside. Even if women get suitable jobs, their attrition rate is often high for reasons including childcare, elderly care, family's relocation, or lack of permission (Women's Web, 2019).

C. Work-place Issues: Women's protection against their job insecurity is mere box-ticking exercises (Mustafa, 2019). Educated working women are often victimized by an invisible yet commanding 'Glass Ceiling' (Maxwell, 2007) and gender-stereotyping (Rahman \& Islam, 2013) with regard to their career advancement (Rahman \& Islam, 2019). Only $0.7 \%$ of the females are able to climb to managerial-level of total workforce (lmisbbs.gov.bd, 2016). They are paid 30\% less than their male-counterparts and pressurized by their coworkers to quit jobs and misunderstood by their family on their roles as mothers (Women's Web, 2019).

D. Legal Issues: Half of $89.15 \%$ of adherents of Islam are women (Bangladesh Bureau of Statistics, 2008, p.129, 85) who face challenges imposed by inheritance inequality Shariah law that violates gender equality, rights and opportunities to enhance their economic position, according to articles 19 (1), 19 (2), 27, 28 (1) and 28 (2) of the constitution of Bangladesh 1972 (Ministry of Law, Justice and Parliamentary Affairs, Bangladesh, 2008) and fundamental human rights under articles 7, 17(1) and 17(2) of Universal Declaration of Human Rights (UDHR) (Shoma, 2019).

E. Political Issues: Policy implemented to preserve women's socio-economic rights by the SME Foundation that dedicated to support women entrepreneurship along with initiating National Action Plan (Ministry of Women and Children Affairs, Bangladesh, 2008) and "Seventh Five Year Plan of 2016-2020" is inadequate. The tripartite partnership by Bangladesh government, United Nations Capital Development Fund, and Bangladesh Bank also failed to generate a credit guarantee scheme (CGS) of US $\$ 0.2$ million for women entrepreneurs (Shoma, 2019).

F. Education system-industry gap: The teaching method of graduate education differs from vocational schools. The technical skills are significantly greater of a vocational school-graduate compared to a university graduate; while academic research abilities are significantly higher of a university graduate than a vocational school-graduate. The upscale employers hire female candidates, most of the organizations prefer graduates from mainly the prestigious universities (Kelly, 2018-19).

\subsection{Female Graduates and Entrepreneurship}

The graduate entrepreneurship is business activity by university graduates (Yusoff, Ahmad, \& Halim, 2017). To achieve success as female graduate entrepreneurs, the creative females must possess a T-shaped skill-package, indepth market know-how besides communication skills, adaptability, tenacity, resilience, proactiveness, commercial acumen, and establish networks, use social media (Kelly, 2018-19) and career-sites such as LinkedIn to recognize opportunities. Women entrepreneurs with graduation has outnumbered their male counter-parts in the capital of Bangladesh. With gradual changes in social and structural factors; the graduate women are increasingly entering and managing SMEs including boutiques, handicrafts, parlors, clinics, restaurants and export-oriented establishments (Sultana, 2012). SMEs play a key role in economic development and job creation (Abdin, 2014) (Yunus, 2017) by introducing new inventions into the market (Chowdhury \& Alam, 2017). A study by (Cornish, 2017) found that, as innovators, educated women with full credentials to recognize opportunities to improve employment prospects are no less than men and contribute to economy. 


\subsection{Sustainable Development Agenda and Entrepreneurship}

Two of the Sustainable Development Goals of UN Agenda (2030) that are aimed at "sustained, inclusive and sustainable economic growth, full employment and decent work for all" (SDG-8), and "achieve gender equality and empower for all women and girls (SDG-5)" (www.sdgfund.org, n.d.) (Global Economic Monitoring Unit, 2018) in developing countries could possibly be achieved by year-2030 if women' participation in workforce is increased by $10 \%$ during the next 5 years (www.dhakatribune.com, 2017). Quality education (SDG 4) is the key to achieve all the SDGs. Graduate women with higher "value-added" and "impactful" participation to economy, positively would contribute to their family and community, which will have transformational benefits for other SDGs (Khatun \& Afroze, 2018).

Economic growth in a country is positively associated with the level of female entrepreneurial activity (Raghunandan, 2018). Unfortunately, the potential for graduate female-owned SMEs to contribute to national GDP has been limited (Islam, Jantan, Hunt, Rahman, \& Abdullah, 2019). Empowering women with more education may lead to achieve their goals (Weber and Ahmed, 2014), and sustainable livelihood (Ferdousi \& Mahmud, 2019), which are mandatory pre-requisites for sustainable development (Rahman \& Bari, 2016), and for a better future (Li, Ahmed, \& Qalati, 2019).

\section{Methodology}

The review paper uses data from published databases including Scopus, Scholar Google, Emerald, Pro Quest, ScienceDirect and adopts the following steps:

Step 1. Formulating research question and objectives to position the subsequent analysis (Jesson, Matheson, \& Lacey, 2011).

Step 2. Searching the existing literature using exhaustive coverage strategy to ensure all relevant studies are included and all-inclusive knowledge base are used to build the conclusion (Paré, Trudel, Jaana, \& Kitsiou, 2015) by in-depth studying of documents, recordings and other printed and verbal materials.

Step 3. Screening information materials, deciding on their relevance (Petticrew \& Roberts, 2006) to enhance objectivity and eliminate biases and extracting data based on research objectives and question (Okoli \& Schabram, 2010).

Step 4. Analyzing the extracted data evocatively and presenting it as a new addition to the existing literature-base (Jesson, Matheson, \& Lacey, 2011). Scoping reviews strategy is used as it involves thorough scoping of grey area to identify research gaps in the existing literature (Paré, Trudel, Jaana, \& Kitsiou, 2015), and analyze consequences (Daudt, van Mossel, \& Scott, 2013).

\section{Analysis and Discussion}

\subsection{Consequences of prevailing issues}

The prevailing issues discourage the graduate women to either apply for jobs or retain in jobs. Such scenario adversely affects Bangladesh's commitment towards the discussed agenda of SDGs (www.bd.undp.org/, 2019). With the mushrooming of fresh female graduates every year, the struggle to find jobs in a competitive labor market leads to lower confidence and interest (Cutura, 2010), under-performance (Ahmed M. U., 2014), and lower quality of their lives (Nowak \& Dahal, 2016). The average skill-level of labor market declines due to the gender inequality in education, which adversely affects economic growth (Pervaiz, Muhammad, Sajjad, \& Amatul, 2011). 


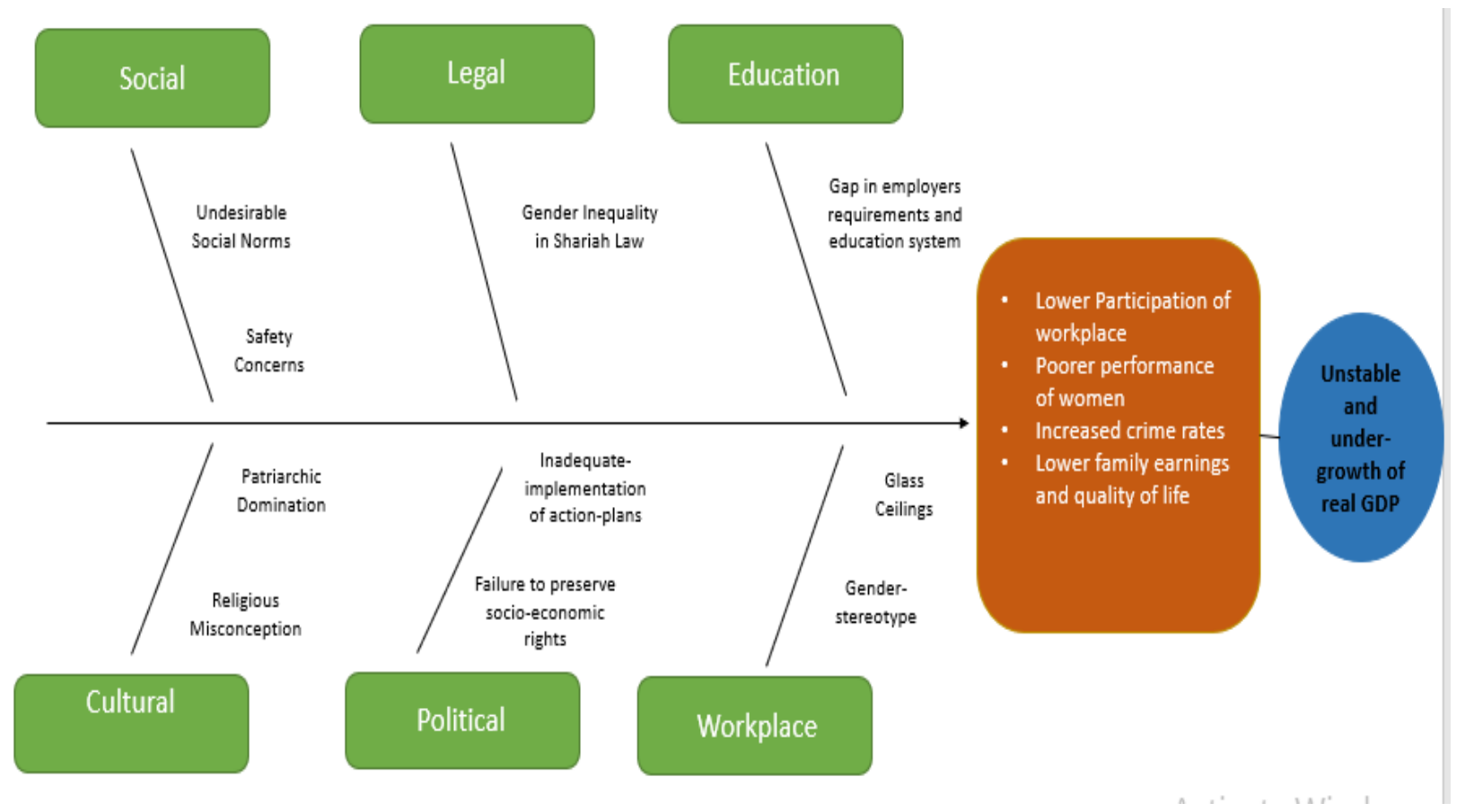

\section{Figure 1: Issues faced by unemployed Graduate Entrepreneurs and consequences}

Also, the unutilized or underutilized human capital hampers personal health and environmental protection, raises crime rates (Hawkes \& Ugur, 2012), delivers little-value and limits economic growth (Sen, A., 1999). (Nowak \& Dahal, 2016) showed, low investment in human capital leads to under-growth of real GDP per capital. In short, as an outcome of the issues faced by the female graduates, the consequences curtail the country's potential to achieve fullcapacity economic growth (Islam \& Dogra, 2011) (Morched \& Jarboui, 2018).

\subsection{Necessity for Graduate Females to Join Entrepreneurship}

Without the graduate women's full-fledged participation in the workforce, the human capital cannot be enhanced in a country. (UN Women, 2015-2016) rightly points out: "when more women work, the economies grow". Introducing entrepreneurship to the unemployed female graduates could be one of the gateways to women's economic freedom and self-worth. A self-dependent woman tends to create positive vibe around her and this sense of goodness is reflected on her family (Sen, 2000). Woman, as an entrepreneur, is economically more powerful than as a mere worker (Pandey, 2015) as she develops herself as a significant alternative to a wage-based employment and creates jobs for others.

Education acts as positive stimulus to business growth and performance (Ekpe, Mat, \& Razak, 2011). Given average women spending 90 cents per USD on their children's education, health and nutrition as opposed to their male counterparts, who spend only 30-40 cents per USD on the same (http://bids.org.bd, 2018); graduate women would yield more transformational benefits through investing into their families and communities to be more educated and better-equipped. The drive of Bangladesh to become a middle-income country (MIC) by 2021, a GDP growth of $7.5 \%-8 \%$ (ADB, 2016) would be necessary, for which transforming the unutilized educated female workforce into productive human capital would be essential.

High-education reduces gender-discrimination (Delavande \& Zafar, 2013) (Khurshid \& Saba, 2017), and leads to opportunity-based (as opposed to necessity-based) entrepreneurship (Li, Ahmed, \& Qalati, 2019) (Begum, Sultana, \& Islam, 2019) with possibilities of creating high-impact SMEs. SMEs arguably should perform better if they are led by graduates, who aim to be profitable, with sense of social conscience and lead to healthy competition in market. Their innovation and attitude would dictate greater entrepreneurial success (Sahedan, Jaafar, Nathan, \& Badariah, 2018), which might be absent among the regular entrepreneurs. The superiority of graduate women to generic women as entrepreneurs are reflected in their characteristics too, as the former are more ambitious, enlightened and comfortable 
to work under pressures; possess enhanced entrepreneurial qualities including self-confidence, responsiveness, timemanagement, foresights; and have greater grasp over resources (Sultana, 2012).

Graduate women have greater opportunities to start ventures (Li, Ahmed, \& Qalati, 2019), earning potential (Nowak \& Dahal, 2016), control over wealth-creation and sustainability (Alam, Jani, \& Omar, 2011); sense of freedom and security (Akhalwaya \& Havenga, 2012); greater empowerment, autonomy and work-life balance (Mohamad \& Bakar, 2017) (Kanapathipillaii \& Azam, 2019). Marketing assistance (Jahed, Kulsum, \& Akhter, 2011) and financing are easier for them to avail (Abdulsaleh \& Worthington, 2013), as creditors show more willingness to provide help to them (Ogubazghi \& Muturi, 2014). With improved knowledge creation activities (Eniola \& Dada, 2018), training, work experience (Tambwe, 2015), innovation supplements reduces risks, pioneer in market-exploitation (Ionescu \& Dumitru, 2015) and lead to business-success (De Silva, Howells, \& Meyer, 2018).

\section{Conclusion}

Though female entrepreneurs have reached the global market and compete well with the male entrepreneurs; the necessity of graduate female entrepreneurship is still overlooked. They offer huge potential to take a long-term view of their businesses. As entrepreneurs, the graduate women can achieve greater success with their greater selfconfidence, entrepreneurial knowledge through work experience, passion and skills. With the high correlation among education and firms' survival, growth, success, and profitability, they have turned to the agents of social and economic changes with their dedicated participation in diverse socio-economic activities. The Bangladeshi females are "enterprising by nature", who just need proper guidelines and support to grow. Its high-time that women should get their deserving respect, care and attention from society. A sustainable economy can be achieved only if the graduate females are made fit enough to compete shoulder to shoulder with men.

\section{Recommendation and Future Research}

The stakeholders including the authorities, Government and policy-makers, banks, financial institutions, universities of Bangladesh need to adopt rational initiatives to mitigate issues faced by the graduate females and encourage them towards sustainable entrepreneurship. The present study recommends the following:

- The Government should invest in trainings, field-studies, and development programs for women; collaborate with representatives of women entrepreneurs, private sectors, development partners; enact gender-friendly education policy and revise property inheritance laws to protect graduate female's interest.

- Banks may introduce "target-based" and "collateral-free loans" (Shoma, 2019), digitalized financial services through mobile applications (UNCDF, 2019) for the graduate women.

- $\quad$ The qualified females should be hired to by the female-owned SMEs to capitalize their multitasking capabilities.

- $\quad$ The NGOs such as, Grameen Bank, Gonoshasthaya Kendra (People's Health Centre), BRAC (Bangladesh Rural Advancement Committee), CARE International, Oxfam, UNDP, UNICEF and USAID should come forward towards graduate women's betterment (Khatun \& Afroze, 2018).

- Women-friendly market-places with secure commuting and technology-oriented venturing options such as "digitalization" should be introduced to allow them to operate from home.

- Social awareness campaigns, need-based technical and vocational training, industrial-academic collaboration (Shoma, 2019) programs can be conducted by club/forums of universities.

- A whole-hearted support is also required from families and communities. The patriarchal mind-set should improve to ensure women's right to pursue careers.

In order to facilitate graduate female entrepreneurship in the SME sector, enhance sustainability of the sector and convert it into a catalyst for economic growth of Bangladesh, the practical approaches must be undertaken.

Like other studies, the present study contains limitations too. The study is based on systematic literature review, for which the outcome of the research may be generalizable for the overall female entrepreneurs to some extent. A 
detailed study could be conducted among unemployed female graduates to know their intention for being entrepreneurs and the outcomes of their running successful SMEs. Furthermore, the results could be compared with generic female entrepreneurs or with other unemployed male graduates of Bangladesh.

\section{References}

Abdin, M. (2014). Vision 2021: The Role of Small and Medium Enterprises in Bangladesh Economy. Retrieved from http://dx.doi.org/10.2139/ssrn.2465763

Abdulsaleh, A., \& Worthington, A. (2013). Small and Medium-Sized Enterprises Financing: A Review of Literature. International Journal of Business \& Management, 8(1), 36-54.

ADB. (2016). What Bangladesh Needs to do to Move to a Lower Middle Income Country. Retrieved 8 2019, 12, from www.adb.org/news/features/bangladesh-challenges-and-opportunities-moving-upper-middle-income-status

Ahmed, M. U. (2014). Women entrepreneurship development in the Small and medium enterprises in Bangladesh: Prospects, realities and policies. International Journal of SME Development, 1(1), 1-32. Retrieved from www.smef.org.bd

Akhalwaya, A., \& Havenga, W. (2012). The Barriers that Hinder the Success of Women Entrepreneurs in Gauteng, South Africa. OIDA International Journal of Sustainable Development, 3(5), 11-28.

Alam, S. S., Jani, M. M., \& Omar, N. A. (2011). An Empirical Study of Success Factors of Women Entrepreneurs in Southern Region in Malaysia. International Journal of Economics and Finance, 3(2). Retrieved from www.ccsenet.org/ijef

Alauddin, M., \& Chowdhury, M. M. (2015). Small and Medium Enterprise in Bangladesh-Prospects and Challenges. Global Journal of Management and Business Research: C Finance, 15(7).

Ball, C. (2018/19). The Graduate Labor Market in 2018. What Do Graduates Do?

Bangladesh Bureau of Statistics. (2018). Improving of Labour Statistics and Labour Market Information System through Panel Survey (LMIS) Project. Bangladesh Bureau of Statistics with technical support from the World Bank. Retrieved from http://203.112.218.65:8008/WebTestApplication/userfiles/Image/LatestReports/LFS_2016-17.pdf

bbs.portal.gov.bd. (2016). Bangladesh Education Statistics. Bangladesh Bureau of Statistics.

Begum, M., Sultana, T., \& Islam, I. B. (2019). A Critical Overview on Women Entrepreneurship through Poultry farming in Bangladesh. Journal of Emerging Technologies and Innovative Research (JETIR), 6(6), 888-896.

Bosma, N. (2013). The Global Entrepreneurship Monitor (GEM) and its impact on entrepreneurship research. Foundations and Trends in Entrepreneurship, 9, 143-248.

Chowdhury, M., \& Alam, Z. (2017). Factors affecting access to finance of small and medium sized enterprises(SMEs) in Bagladesh. USV Annals of Economics and Public Administration, 2(26), 55-68.

Chowdhury, N., Mintoo, N. A., Chowdhury, M. F., \& Ahmed, M. (2010). A gender action plan: Minding financing, marketing, technology and mindset gaps. Government of the People's Republic of Bangladesh, Ministry of Industries, Dhaka.

Cornish, L. (2017, September 12). Are women entrepreneurs the key to global economic development? Retrieved from https://www.devex.com/news/are-women-entrepreneurs-the-key-to-global-economic-development-91010

Cutura, J. (2010). Women's economic empowerment-trends and good practices on women's entrepreneurship in the OSCE region. Organization for Security and Co-operation in Europe. Vienna: OECE Working Paper No. 553 .

Daudt, H. M., van Mossel, C., \& Scott, S. J. (2013). Enhancing the scoping study methodology: a large, interprofessional team's experience with Arksey and O’Malley's framework. Medical Research Methodology, 13(48).

De Silva, M., Howells, J., \& Meyer, M. (2018). Innovation Intermediaries and Collaboration: Knowledge-Based Practices and Internal Value Creation. Research Policy, 47(1), 71-85.

Delavande, A., \& Zafar, B. (2013). Gender Discrimiantion and Social Identity: Experimental Evidence from Urban Pakistan. FRB of New York Staff Report.

Dhaka Tribune. (2019, June 28). Retrieved from Rise of the educated unemployed: https://www.dhakatribune.com/opinion/op-ed/2019/06/28/rise-of-the-educated-unemployed

Ekpe, I., Mat, N., \& Razak, R. C. (2011). Attributes, Environment Factors and Women Entrepreneurial Activity: A Literature Review. Asian Social Science, 7(9), 124-130. 
Eniola, A. B., \& Dada, D. (2018). The Performance of Women Entrepreneurs: Human and Financial Capital. Triple A Research Journal of Social Science \& Humanity, 2(1), 31-36.

Ferdousi, F., \& Mahmud, P. (2019). Role of social business in women entrepreneurship development in Bangladesh: perspectives from Nobin Udyokta projects of Grameen Telecom Trust. Journal of Global Entrepreneurship Research, 9(58), 1-21. doi:https://doi.org/10.1186/s40497-019-0184-

Global Economic Monitoring Unit. (2018, 2 1). High youth unemployment presents a daunting challenge for policymakers around the world. World Economic Situation and Prospects-Monthly Briefing. Retrieved from http://www.bit.ly/wespbrief

Hawkes, D., \& Ugur, M. (2012). Evidence on the relationship between education, skills and economic growth in lowincome countries: A systematic review. London: EPPI-Centre, Social Science Research Unit, Institute of Education, University of London.

http://bids.org.bd. (2018). BIDS Almanac. Retrieved from Women Entrepreneurs in SMEs: Bangladesh Perspective: http://bids.org.bd/uploads/events/almanac2018/TS-2_P-3.pdf

Ionescu, A., \& Dumitru, N. (2015). The Role of Innovation in Creating the Company's Competitive Advantage. Eco Forum, 4(1), 99-104.

Islam, M. S., \& Dogra, S. (2011). Women Empowerment in Bangladesh: The Rise of the Other Half. ISAS.

Islam, M., Jantan, A., Hunt, A., Rahman, M., \& Abdullah, M. (2019). Exploration of Barriers Faced by Female Graduate Entrepreneurs in Bangladesh. Entrepreneurship and Sustainability Issues, 7(2), 1000-1014. doi:http://jssidoi.org/jesi/

Jahed, M., Kulsum, U., \& Akhter, S. (2011). WOMEN ENTREPRENEURSHIP IN BANGLADESH: A STUDY ON SUPPORT SERVICES AVAILABLE FOR ITS DEVELOPMENT AND GROWTH. Global Management

Review.

Jesson, J., Matheson, L., \& Lacey, F. M. (2011). Doing Your Literature Review: Traditional and Systematic Techniques. Los Angeles \& London: SAGE Publications.

Kabeer, N. (2012). Women's economic empowerment and inclusive growth: Labour markets and enterprise development. Centre for Development Policy and Research, School of Oriental \& African Studies. London: University of London.

Kanapathipillaii, K., \& Azam, S. F. (2019). WOMEN ENTREPRENEURS PATH TO SUCCESS: AN INVESTIGATION OF THE CRITICAL SUCCESS FACTORS IN MALAYSIA. European Journal of Human Resource Management Studies, 3(1), 106-129. doi:10.5281/zenodo.3375708

Kelly, P. (2018-19). Entrepreneurship and the Creative Graduate. What Do Graduates Do?, p. 17. Retrieved from www.hecsu.ac.uk

Kempster, H. (2018/19). Career Expert Insights: Gender in the graduate labour market. What Do Graduates Do?, p. 13. Retrieved from www.hecsu.ac.uk

Khatun, F. (2018). Women's participation in the job market. Retrieved from https://www.thedailystar.net/supplements/womens-participation-the-jobmarket-1545181

Khatun, T., \& Afroze, S. (2018). The Relationship between Gender Equality in Bangladesh and Middle-Income Country Status by 2021. Australian Academy of Accounting and Finance Review (AAAFR), 4(2), 66-79.

Khurshid, A., \& Saba, A. (2017). Contested Womanhood: Women's education and (re) production of gendered norms in Rural Pakistani Muslim Communities. Discourse: Studies in the Cultural Politics of Education, 39, 550563.

Kletzer, L., \& Fairlie, R. (2003). The Long-Term Costs of Job Displacement for Young Adult Workers. Industrial and Labor Relations Review, 56(4). doi:10.2307/3590963

Li, C., Ahmed, N., \& Qalati, S. A. (2019). Impact of Gender-Specific Causes on Women Entrepreneurship: An Opportunity Structure for Entrepreneurial Women in Rural Areas. Journal of Entrepreneurship \& Organization Managemen, 8(270).

lmisbbs.gov.bd. (2016). Quarterly Labor Force Survey of BBS.

Maxwell, P. W. (2007). Success strategies for the female project manager [Seminar Paper]. PMI Global Congress.

Ministry of Law, Justice and Parliamentary Affairs, Bangladesh. (2008). The Constitution of the People's Republic of Bangladesh 1972. Dhaka.

Ministry of Women and Children Affairs, Bangladesh. (2008). Dhaka. 
Mohamad, M., \& Bakar, M. (2017). Malay Women Entrepreneurial Success: Challenges and Barriers. International Journal of Accounting, Finance and Business, 2(5), 77-82.

Morched, S., \& Jarboui, A. (2018). Does female entrepreneurship add in economic growth? Evidence from twentyfive countries. Journal of Academic Finance, 9(2), 20-35.

Musa, Babangida Muhammad ; Semasinghe, D. M. (2013). ENTREPRENEURSHIP AND UNEMPLOYMENT: A LITERATURE REVIEW. International Conference on Business \& Information.

Mustafa, A. (2019). An Analysis of the Nexus between Female Labour Force Participation and Women's Empowerment in Bangladesh. Dhaka: BRAC University.

Nowak, A. Z., \& Dahal, G. (2016). The contribution of education to economic growth: Evidence from Nepal. International Journal of Economic Sciences, 22, 22-41. doi:10.20472/ES.2016.5.2.002

OECD. (2012). Gender Equality in Education, Employment and Entrepreneurship. Final Report to the MCM. Retrieved from http://www.oecd.org/employment/50423364.pdf

Ogubazghi, S. K., \& Muturi, W. (2014). The Effect of Age \& Educational Level of Owner/Managers on SMEs' Access to Bank Loan in Eritrea: Evidence from Asmara City. American Journal of Industrial and Business Management, 4(11), 632-642.

Okoli, C., \& Schabram, K. (2010). A Guide to Conducting a Systematic Literature Review of Information Systems Research. SSRN Electronic Journal.

Paré, G., Trudel, M. -C., Jaana, M., \& Kitsiou, S. (2015). Synthesizing Information Systems Knowledge: A Typology of Literature Reviews. Information \& Management, 52(2), 183-199.

Pervaiz, Z., Muhammad, I., Sajjad, A., \& Amatul, R. (2011). Gender Inequality and Economic Growth: A Time Series Analysis for Pakistan. Middle East Journal of Scientific Research, 10, 434-439.

Petticrew, M., \& Roberts, H. (2006). Systematic Reviews In the Social Sciences: A Practical Guide. Malden, MA: Blackwell Publishing Co.

Raghunandan, V. (2018). Changing Equations: Empowerment, Entrepreneurship and the Welfare of Women. Journal of International Women's Studies, 19(14), 187-198. doi:http://vc.bridgew.edu/jiws/vol19/iss3/14

Rahman, M. A., \& Islam, M. J. (2019). THE EFFECT OF GENDER STEREOTYPE AND GLASS CEILING ON THE CAREER ADVANCEMENT OF WOMEN ACADEMICS: A STUDY ON PRIVATE UNIVERSITIES OF BANGLADESH. Daffodil International University Journal of Business and Entrepreneurship, 12(1), 114.

Rahman, M., \& Bari, E. (2016). The Political Economy of Change: Escaping the Middle-income Trap: Perspectives from Bangladesh. Center for Policy Dialogue.

Rahman, R. I., \& Islam, R. (2013). Female labour force participation in Bangladesh: trends, drivers and barriers. ILO Asia- Pacific Working Paper Series, ILO DWT for South Asia and the Country Office for India, India.

Sahedan, N., Jaafar, N., Nathan, S., \& Badariah, S. (2018). Prominent Entrepreneur Traits for Income Generating Programs Performance. Advances in Business Research International Journal, 4(2), 9-19.

Salik, M., Zhiyong, Z., Guoyuan, S., \& Jiayong, L. (2015). Making People Employable: Reforming Higher Education in China. Beijing, China: nstitute for International and Comparative Education, Beijing Normal University.

Sarfaraz, L., Faghih, N., \& Majd, A. (2014). The Relationship Between Women Entrepreneurship and gender equality. Journal of Global Entrepreneurship Research, 4(1).

Sen, A. (1999). Development as Freedom. Oxford: Oxford University Press.

Sen, A. (2000). Women's Agency and Social Change. In Development as Freedom (pp. 189-203). New Delhi: Oxford University Press.

SENGUPTA, J. (2019, March 8). India Matters. Retrieved July 7, 2019, from Observer Research Foundation (ORF): https://www.orfonline.org/expert-speak/educated-unemployed-women-48737/

Shoma, C. D. (2019). Gender is a Human Rights Issue: The Case of Women's Entrepreneurship Development in the Small and Medium Enterprise Sector of Bangladesh. Journal of International Women's Studies, 20(7), $13-34$.

Sultana, I. (2012). The Emerging SME Women Entrepreneurs in Dhaka City. Journal of Business Studies, XXXIII(1), $15-34$.

Tambwe, M. A. (2015). The Impact of Entrepreneurship Training on Micro \& Small Enterprises' Performance in Tanzania: The Case of Food Vendors in Ilala District Dar Es Salam. Business Education Journal, 1(18), 1-16.

The Daily Star. (2018, March 08). Female graduates most unemployed. Retrieved from https://www.thedailystar.net: https://www.thedailystar.net/business/female-graduates-most-unemployed-1545148 
UN Women. (2015-2016). Progress of the World's Women: Chapter 2.

UNCDF. (2019). microentrepreneursasia. (W. M.-M. barriers?, Producer, \& UNCDF) Retrieved 04 27, 2019, from www.microentrepreneursasia.com/women-micro-merchants-in-mangladesh: www.microentrepreneursasia.com/women-micro-merchants-in-mangladesh

Women's Web. (2019, March 4). 7 Reasons Why 68\% Educated Urban Indian Women Are Unemployed Despite Better Education. Retrieved from https://www.womensweb.in/2019/03/indian-women-education-employmentmismatch-mar19wk2sr/

www.bd.undp.org/. (2019). UNDP Bangladesh. Retrieved from https://www.bd.undp.org/content/bangladesh/en/home/sustainable-development-goals/goal-5-genderequality.html

www.dhakatribune.com. (2017, March 8). Study: 10\% rise in women workforce to raise Bangladesh GDP by 1\%. Retrieved from https://www.dhakatribune.com/business/2017/03/08/study-10-rise-women-workforce-raisebangladesh-gdp-1

Yunis, M., Hashim, H., \& Anderson, A. (2019). Enablers and Constraints of Female Entrepreneurship in Khyber Pukhtunkhawa, Pakistan: Institutional and Feminist Perspectives. Sustainability, 11(27).

Yunus, M. (2017). Entrepreneurship: A Global Social Movement. Sage Publications.

Yusoff, A., Ahmad, N. H., \& Halim, H. A. (2017). Agropreneurship among Gen Y in Malaysia: The Role of Academic Institutions. Handbook of Research on Small and Medium Enterprises in Developing Countries, 2347. doi:10.4018/978-1-5225-2165-5.ch002 